\title{
1965 and the Global Intellectual Afterlife of Malcolm X
}

\section{Zareena Grewal}
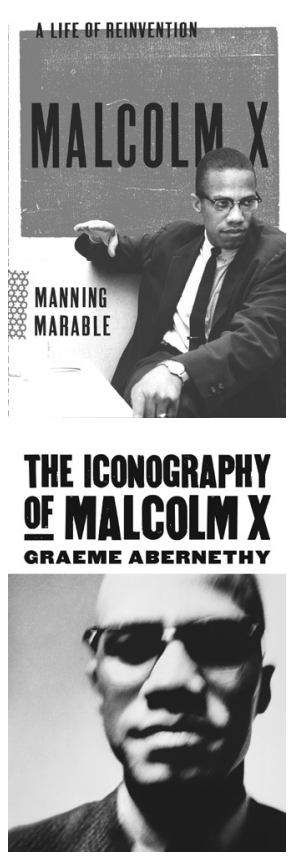
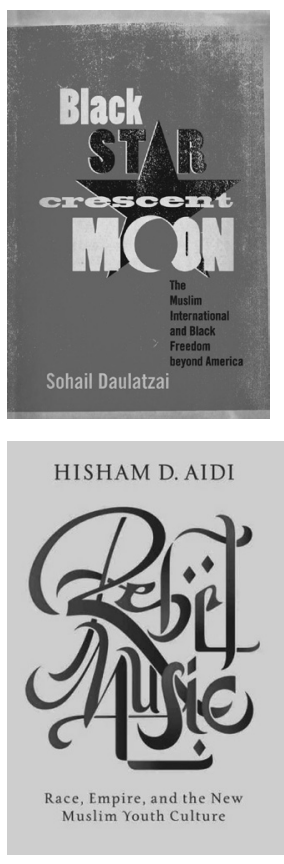

MALCOLM X: A Life of Reinvention. By Manning Marable. New York: Viking. 2011.

BLACK STAR, CRESCENT MOON: The Muslim International and Black Freedom beyond America. By Sohail Daulatzai. Minneapolis: University of Minnesota Press. 2012.

THE ICONOGRAPHY OF MALCOLM X. By Graeme Abernethy. Lawrence: University Press of Kansas. 2013.

REBEL MUSIC: Race, Empire, and the New Muslim Youth Culture. By Hisham Aidi. New York: Vintage Books. 2014.

On February 21, 1965, Malcolm X was assassinated by five men linked to the Nation of Islam, 
aided by the criminal negligence, if not the direct cooperation, of the FBI and the NYPD. One can only imagine what our world might have looked like today had his brilliant career not been cut short so brutally. By November of 1965, Alex Haley's The Autobiography of Malcolm X was published, becoming an instant bestseller and the enduring, dominant representation of Malcolm's life and thought. Manning Marable's Malcolm X: A Life of Reinvention is a revisionist history that draws upon a rich archival record including unpublished chapters of Haley's manuscript and early speeches from private archives. Marable successfully upends much of the conciliatory racial narrative that Haley's Autobiography imposes on Malcolm X, in part by excavating Haley's own intellectual genealogy as a liberal Republican and exposing his political investment in writing the book as a cautionary tale about racial segregation. (9) Marable challenges Haley's framing of Malcolm X as an integrationist evolving "firmly within mainstream civil rights respectability at the end of his life" (10). In fact, Haley omits and glosses over key events and achievements in the last year of Malcolm X's life such as his international travel after the hajj trip (as well as a 1959 trip to Saudi Arabia) and his primary organization, the Organization of Afro-American Unity, material that figures centrally in Marable's Malcolm X. ${ }^{1}$ While Marable adheres to the conventions of the genre of biography, he writes Malcolm X's life story as an intellectual history, paying special attention to the radical internationalist strain in Malcolm X's thought that has too often been overlooked or diluted in scholarly and popular representations. In Marable's account, Malcolm X's internationalism is firmly grounded in his parents' advocacy of Marcus Garvey's gospel of racial uplift and self-mastery. Capitalist, separatist, and pan-African humanist, Garvey's vision of a transnational politics of black liberation, Marable argues, drew on thinkers as diverse as Frederick Douglass, Andrew Carnegie, Ralph Waldo Emerson, Horatio Alger, and Benjamin Franklin (18). One of the great strengths of Marable's work is his ability to account for the continuities, tensions, and contradictions in Malcolm X's thought over time. Marable demonstrates how the religio-political influences of Garvey's teachings shaped his views even as a young man in Harlem. While his views converged with many of the teachings of the Nation of Islam (NOI), the moral vision of the NOI resonated even more deeply for him and was ultimately more profoundly revolutionary because, Marable argues, it was more explicitly theological than Garvey's vision $(54,89)$. Even once he became a Sunni Muslim, Malcolm X's religio-political views were far more radical and revolutionary than the way they are often memorialized. For example, Marable documents how his travels abroad made Malcolm X much more critical of capitalism and its genetic relationship to racism and how he became much more intrigued by the appeal of socialism to the post-colonial third world. This is despite the fact that for years Malcolm X had espoused the virtues of entrepreneurial capitalism, echoing Elijah Muhammad and his Garveyite parents. Troubled by the consistent cooptation of "one of America's sharpest and unrelenting critics" by the same government that systematically and illegally harassed and spied on him, Marable bemoans the 1999 issuance of 
a hundred million US postal stamps of Malcolm X as the completion of a long process of erasure, de-politicization, domestication and "Americanization." ${ }^{2}$ In its press statement, the US Postal Service characterized Malcolm X as an advocate of "a more integrationist solution to racial problems" (9).

In the wake of the repatriation of an archive of Malcolm X's private papers and travel diaries at the Schomburg Center for Research in Black Culture in 2003 and Marable's publication in 2011, scholars across fields such as US history, American studies, critical race and ethnic studies, political science, and Islamic studies are reconsidering the last year of Malcolm X's life, as well as his legacy and impact over time. I count myself among a growing cohort of interdisciplinary scholars whose work extends the project of recuperating Malcolm X's radical humanism and his global legacy, which collectively challenge the "Americanization" of Malcolm X. The diverse set of historical, ethnographic, and culture studies works examined here locate Malcolm X in broader intellectual histories and in different global imaginaries and moral geographies, from black radicals and disaffected Muslim youth to avid consumers of popular visual and musical cultures that span the globe. ${ }^{3}$

Graeme Abernethy's fascinating The Iconography of Malcolm $X$ blurs the distinction between cultural history and intellectual history, and while his work is far less ambitious than the others discussed below, the force of his argument benefits from his steady focus on an archive of visual representations of Malcolm $\mathrm{X}$ and the diverse (and global) publics that consume them. Abernethy tracks the paradoxical ways in which Malcolm X's image can stand in for racial reconciliation and enduring racial conflict. Abernethy labors to recuperate the radical political thought of Malcolm X from the respectability politics and nostalgia that occludes his radical political differences with other Civil Rights leaders. Although Malcolm X dismissed Martin Luther King Jr. as "Uncle Martin" even as late as January 5, 1965, the photograph of a brief (mediated) encounter between the two men smiling and shaking hands in a corridor of the US Capitol was widely celebrated after their assassinations. Abernethy skillfully analyzes the memorial function of this image and many, many others - how it reconciles the two figures more "in death than may have been possible in life" (63). He then follows the image to the Obama campaign in 2008, when it circulated with Obama's photo-shopped face atop Malcolm X's body. The image of their fused bodies is a sharp contrast to President Obama's striking silence about Malcolm $\mathrm{X}$, such as on the fiftieth anniversary of his assassination or in his 2009 "Muslim World Address" in Egypt. After all, Obama named Malcolm X as a major intellectual influence and a favorite literary figure in his memoir, penned long before he nurtured presidential ambitions (223).

Abernethy helpfully divides the cultural afterlife of images of Malcolm X into three periods, each punctuated by a transformative visual text. The first period is the Civil Rights Era, beginning with the news documentary The Hate that Hate Produced (1959), which presented Malcolm X as a dangerous demagogue. Abernethy demonstrates how Malcolm X powerfully challenged this misrepre- 
sentation throughout his life. Abernethy's second period, Black Power, begins with the assassination and the publication of Haley's Autobiography in 1965. Abernethy's account of the influence of the book in shaping cultural memory, not only by narrating with words but also with its cover images, is particularly compelling. Abernethy's third period, the era of hip hop, begins with Spike Lee's 1992 film Malcolm X and extends to contemporary hip hop artists who inherit all of the different iconic representations of Malcolm X - remixing images, versions, and visions of the man often in surprising and inventive ways.

Abernethy weaves a history of Malcolm X's own ideas about the power of images into his own analysis of images of Malcolm X. He argues that Malcolm X not only developed his own theory of the power of the image (what he termed "the science of imagery") but that Malcolm X must be recognized as "a practitioner of the science of imagery" (13). Abernethy documents how Malcolm X exerted various degrees of control over his image in part through his collaborations with journalists, photojournalists, and art photographers. Abernethy's focus on Malcolm X's ideas about visual images expands the intellectual histories of Robert E. Terrill (Malcolm X: Inventing Radical Judgment) and Marable, who notes that long before "postmodernists wrote about 'white privilege,' Malcolm spoke about the destructive effects of racism upon both its victims and its promulgators" (484). Abernethy constructs a fascinating genealogy of the debts of Malcolm X's theory of visual representation to Elijah Muhammad's concept of tricknology, a theory of ideological inscription that also incorporates concepts from modern psychiatry, such as an inferiority complex, but applies them to the scale of races rather than individuals. Abernethy writes that the Nation of Islam, "with its logic of inversion, presented itself as an antidote to the false knowledge and images disseminated by the dominant culture" (36). Interestingly, Abernethy's genealogy of Malcolm X's "science of imagery" also traces the ways Malcolm X was indebted to Christian thinkers, such as Saint Augustine and the visual tradition of Christian iconography, without falling into the bad analytic habit of suggesting that such influences are incongruous with his "authentic" identity as a Muslim or the iconoclastic tradition of monotheism within Islam (93). Abernethy notes that it is Malcolm X's "religious rather than political views that suffer most at the hands of post-humous inscriptions," and although he demonstrates how Malcolm $\mathrm{X}$ 's image is frequently delinked from Islam in the popular imagination during each of his three periods, we learn little about these occluded religious views from Abernethy's text (10).

Sohail Daulatzai's brilliant monograph Black Star, Crescent Moon: The Muslim International and Black Freedom beyond America offers a powerful cultural history of black radical thought that cuts through the problematic framing of Malcolm X as ultimately choosing integration over segregation, even mirroring the scrutiny that Marable directed to the scholarly domestication of Malcolm X back onto Marable's Malcolm X: A Life of Reinvention. For Malcolm $\mathrm{X}$, internationalism (the global "Black Revolution") was the political alternative to integration (the "Negro Revolution") and Cold War liberalism and so his 
anti-imperialism and antiracism were co-constitutive. Malcolm X consistently argued the oppression of US blacks was a human rights (not civil rights) issue that ought to be brought before the United Nations, a prospect, Daulatzai demonstrates, that deeply worried officials in the US State Department and Justice Department in 1964 and 1965. Leaving the Nation of Islam allowed Malcolm $\mathrm{X}$ to pursue his long-standing interest in alliances and collaborations with other activists, however, Daulatzai challenges what he calls Marable's "liberal" account of Malcolm X embracing the Civil Rights movement at the end of his life as well as his acquiescence to neo-Orientalist framings of Islamic radicalism (202). Marable, on the one hand, reads "The Ballot or the Bullet" speech as a mature acceptance of electoral politics as a means to black liberation (484). Daulatzai, on the other hand, counters that Malcolm X's consistent skepticism about the possibilities of racial justice through elections and legislation and his language of decolonization constituted a far more radical vision. This enduring political paradigm, which Daulatzai terms "the Muslim International," destabilizes the Cold War liberal assumptions and narrow nationalism of the Civil Rights movement and its legacy (xxii). It must be emphasized that "Muslim" is not a religious signifier in Daulatzai's Muslim International, nor does it signify a break with the thought of Elijah Muhammad, a crucial distinction from the seemingly similar Afro-Arab geography of liberation posited by intellectual historian Alex Lubin, who suggests that in the last eighteen months of his life Malcolm X's views evolved to include diverse movements such as the PLO, the Muslim Brotherhood, and socialist pan-Arabists on "a singular horizon of faith-based radicalism."

Daulatzai's category of "the Muslim International" aims to capture the interlocking religio-political dimensions of Malcolm X's ideas; although Malcolm X popularized Islam as "the Black Man's religion," the significance and impact of the Muslim (third) world on black radicals cannot be understood in religious rather than political terms. Daulatzai explores what the Muslim third world has meant and can mean in black radical thought from the Cold War to the War on Terror, including but not limited to black Muslims. Of course, this begs the question of how to define black radical thought, a question Daulatzai does not address head-on but comes at indirectly and cumulatively through black artists and thinkers who challenge the conservative and liberal political status quo. The book opens with a characteristically penetrating analysis of President Obama's 2009 inauguration in which Daulatzai demonstrates how the figures of Malcolm X and Martin Luther King Jr. were conjured as the twin poles of Black redemptive possibility, the former exorcized and the latter ossified and domesticated. In addition to inspiring hollow nationalist claims of post-racial triumph, Obama's presidency gave US empire a black face. Daulatzai takes readers deeper, plumbing how "the Muslim International" allowed black radicals to challenge the orthodoxies of the Civil Rights Movement, which tied black liberation to the fate of US empire, by assimilating the logic of anti-communism in the Cold War and anti-terrorism today, to the detriment to black and brown peoples within the US and around the world. 


\section{Zareena Grewal}

In order to track the extent to which Islam and the Muslim third world captured the black radical political imagination, Daulatzai guides readers through a stunning archive of films, novels, music, speeches, poetry, and music. Black Star, Crescent Moon disrupts the boundary between intellectual history and cultural history, tracing Malcolm X's influence on the Revolutionary Action Movement and Black Power but also in the Black Arts Movement and, most compellingly, in hip hop. The scope of Daulatzai's archive and the sensitivity of his close readings of cultural texts are powerful, however, at times one loses sight of the specificity of what the Muslim International signifies over the course of the book. Daulatzai makes a compelling case that the Muslim International operates as an "alternative racial compass that gave [and gives] new political direction for Black quests for freedom," but the needle of the compass clearly moves in many different directions when it is in the hands of black thinkers as diverse as Yasiin Bey (formerly Mos Def), Louis Farrakhan, and Jamil AlAmin (formerly H. Rap Brown), and the needle also points to many different Muslim places (23). Daulatzai's strongest moments are when he shows us what particular Muslim third world geographies/movements mean to black radicals and how they are deployed in particular moments, such as his elegant analysis of the significance of the film The Battle for Algiers. That said, the significance of Algeria is not the same as Ghana, nor is Ghana's significance the same as that of Saudi Arabia, distinctions Daulatzai knows intimately but does not always make explicit for his readers. Daulatzai's Black Star, Crescent Moon is an urgent intervention in transnational intellectual and cultural history, however, the concept of "the Muslim International" loses some of its analytical efficacy over the course of his argument due to the imprecision of its usage. At times, the political category of "the Muslim International" is indistinguishable from, and seemingly interchangeable with, Daulatzai's general references to the Muslim third world as a post-colonial geography.

Hisham Aidi's Rebel Music: Race, Empire, and the New Muslim Youth Culture is similarly invested in documenting the range of ways Malcolm X is a source of political and religious inspiration, in his case for Muslim youth worldwide. Rebel Music balances attention to the specificities of particular youth countercultures around the world and their investments in black and/or Muslim geographies with a remarkably global scope, taking readers to concerts, speeches, nightclubs, and governmental corridors across four continents. He writes: "If Islam is the unofficial religion of hip hop culture, Malcolm X is the prophet, or at the very least, the patron saint; his speeches are quoted, his dress and demeanor imitated" (234). Beginning in the South Bronx at a hip hop concert featuring French rappers Third Eye, Aidi narrates a fascinating and dizzying account of the rise of a global, (black) American dream for racial justice that travels in various forms of subversive music, mixing and transcending languages and genres, zigzagging across borders, absorbing and amplifying local sounds, and cracking the veneer of national cohesion to reveal deep political fractures in stratified societies around the world. 
Foregoing chronological histories and linear narratives, Aidi proves to be an adept guide through global music scenes and Muslim youth countercultures. He expertly weaves imperial, slave, and postcolonial histories of the US, South America, Europe, the Middle East, Asia, and Africa into his narrative of encounters with musicians, fans, intellectuals, and activists, with a keen eye to racial and sexual politics. The breadth of Aidi's account of the mobilization of Muslim youth through popular music is a stunning achievement. Although clearly indebted to Paul Gilroy's Black Atlantic, the Moorish Atlantic of Rebel Music never feels derivative; that said, the citations to research about Muslim diasporas that inform Aidi's arguments are too spare. Malcolm X's shadow looms large over the heads of Muslim youth bent in attentive silence to their headphones and exuberant bodies on throbbing dance-floors around the world, a fact that has not escaped the attention of religious leaders and government officials. Aidi maps the ways Malcolm X inhabits a wide range of moral geographies of radical Muslim youth worldwide. Although their readings of "Brother Malcolm" are diverse and conflicting, Aidi insists that their engagements with Malcolm X's thought are often serious and politically consequential. In the US, immigrant race activists from the Middle East and North Africa who are inspired by Malcolm X and committed to black liberation mobilize against state surveillance and organize campaigns to get their own box on the census, rejecting the "compulsory" whiteness an earlier generation of Arab immigrants fought to achieve (163). In Brazil, the number of mosques has quintupled since 2000, with the mass conversions of youth from the favelas who are discovering Malcolm X in the lyrics of American hip hop and searching for Moorish roots in their family trees (32). In 2011, the young Egyptians whose peaceful Dignity Revolution removed long-standing dictator Hosni Mubarak from the presidential office began reading Haley's Autobiography in droves, making it a local bestseller (233). In France, two new radical political parties - the Natives of the Republic Party and the New Black Panther Party - draw their inspiration from Malcolm X and eschew traditional electoral politics, successfully attracting race-conscious Muslim youth from the banlieues who are disaffected with the integrationist strategies of mainline French Muslim institutions (312). Again and again, Aidi convincingly demonstrates how clumsy the logic of the War on Terror is; the presumption that politically disaffected Muslim youth must be de-radicalized depends on a narrow definition of radical as synonymous with jihadist. Aidi's powerful intervention introduces readers to an alternative, thriving radical strain of Islamic thought that traces its roots to Malcolm X rather than the Egyptian Islamist Sayyid Qutb. The young Muslims he encounters are radical in their absolute commitment against racial injustice and neo-imperialism and Aidi meticulously catalogues their fight songs.

Since the figure of Malcolm X is so thoroughly saturated with both street credibility and Islamic legitimacy for Muslim youth around the world, Muslim religious leaders from a wide range of Muslim sects and traditions compete to claim him as their own. In the US, Aidi considers, on the one hand, the writings of an older African-American Sunni integrationist who argues that if he had 
lived longer Malcolm's Sunni commitments would have led him to disavow his anti-state rhetoric and embrace his American identity, and, on the other hand, the speech of Malcolm X's grandson, Malcolm Lateef Shabazz Jr., who converted to Shii Islam in Syria in 2007 and claimed his late grandfather would have done the same $(235,246)$. In Sudan, rival political parties identified with the Salafi movement and the Muslim Brotherhood propagate different policies and different accounts of Malcolm X's visit to their country to win votes (247). In Yemen, Sufi preachers with global, rock-star followings proclaim Malcolm X a saint and take groups of American Muslim devotees to visit his grave in Hartsdale, New York (248). Interestingly, in order to lay claim to the post-hajj Malcolm X, Muslim leaders who aim to guide young people introduced to his ideas through hip hop must grapple with the moral status of music in Islam. ${ }^{5}$ Aidi plots the range of Islamic views on a spectrum from those Muslims who accept music and dancing without reservation to those who deem it immodest and sinful; he dubs the accepting ("liberal") pole "Sufi" and the latter "Salafi." While it generally works for the cases he describes, his schema is too crude for such a complex religious debate because Sufis sometimes hold what Aidi calls the "puritanical" Salafi position and many Salafis listen to music. What Aidi's analysis leaves underdeveloped is the processes by which Muslim leaders awkwardly reconcile their support for unpopular governments with their invocations of Malcolm X for audiences of Muslim youth who are far more politically radical and rebellious than they are.

To be sure, Muslims' claims to Malcolm X's legacy in service of particular religious agendas are tangential to the core argument of the book. Trained as a political scientist, Aidi's real interest lies in the policies of states that co-opt Malcolm X's legacy (along with Salafi Islam in the Cold War and Sufism in the War on Terror) as a counterterrorism tool, and it is the US government's deployment of soft power in the form of a hip hop "sound diplomacy" (modeled on the Cold War jazz tours) that preoccupies him. Aidi carefully dissects examples of the US government's instrumentalization of hip hop as a de-radicalizing lure; in Tunisia, the US embassy ran a contest to find the next Malcolm X and in Yemen the US embassy hosted a birthday celebration for Malcolm X, perhaps as an attempt to "black-wash" drone operations $(234,253)$. These efforts are not only geared to win the hearts and minds of politically disaffected Muslim youth in Muslim-majority countries but also the young Muslims of Europe's ghettos. Aidi's razor sharp analysis of these state-sponsored initiatives casts US officials' usage of black (Muslim) history to counter Islamism in Europe as a non-violent corollary to US military campaigns in Iraq, Afghanistan, Somalia and Yemen (224). Although much of his book captures the exuberant soundtrack of youthful, utopic dreams set in gritty neighborhoods around the world, Aidi makes a sobering conclusion: for all the energetic and high-minded political mobilization around transnational Islamic cultural formations, nation-states are still the most powerful actors shaping Islamic discourses, identities, and movements in Europe, the Middle East, and the US. 
In my book, Islam is a Foreign Country: American Muslims and the Global Crisis of Authority, I also explore Malcolm X's radical religio-political vision and contextualize it in a transnational, intellectual history of Islam in the United States. ${ }^{6}$ Like September 11, 2001, the year 1965 is a pivotal historical moment in the historiography of Islam in the US, so much so that scholars in this subfield of US history usually invoke the year with the prefixes "pre-" or "post-" attached to it. There is no denying that 1965 is a key rupture point in the story of Islam in the US, but what kind of rupture? One generation ago, scholars writing about American Muslims were locked in cyclical debates in which 1965 figured as a fault line: religious studies scholars delineated whether African-American Muslim communities such as the Nation of Islam (the majority of black Muslims before 1965) were as authentically Islamic as Sunnis (who became the majority of black Muslims after 1965, many inspired by Malcolm X's final conversion) and social scientists determined how to tell the story of Muslim migration to the US in terms of intrusive, aquatic metaphors like "waves," "flows" or "floods."7 1965 is also significant to the history of American Islam because of the passing of the Immigration Act, a direct outcome of the Civil Rights Act, which triggered the immigration of large numbers of Muslims primarily from the Middle East and South Asia. In the context of the Cold War, this generation of highly educated and upwardly mobile immigrants was attractive to the US government as a way to keep ahead of the USSR in technical and scientific fields. These Cold War Muslim immigrants radically transformed the demographic picture of US mosques and some of the pan-Islamists among them reshaped the terms of religious authority and the political priorities of American Muslim institutions: shifting focus from domestic social justice issues toward unjust US foreign policy in Muslim-majority countries and memorializing the post-Mecca Malcolm X as a depoliticized, colorblind universalist. ${ }^{8}$ Thus, 1965 marks several periods of the history of Islam in the US — as a demographic turning point, as the end of Malcolm $X$ 's charismatic and global leadership, and as the beginning in a shift in American Muslim religious and political cultures. However, historical accounts of Islam in the twentieth-century US too often treat 1965 both as a temporal and analytical marker. In such cases, 1965 is used to separate and oversimplify the stories of (separatist) Black Muslims from (integrationist) Immigrant Muslims and (black) Heterodox Islam from (immigrant) Orthodox Islam, as well as (transient/working class) urban immigrants from (middle class) suburban immigrants. ${ }^{9}$ These historical narratives work in tandem with Haley's erasures and misrepresentations in the Autobiography and scholars routinely treat the last year of Malcolm X's life (after his hajj pilgrimage) as a complete break from his thought and work in the Nation of Islam, misrepresenting the conversion to Sunni Islam as sudden rather than gradual, as racial as well as theological. ${ }^{10}$

In order to challenge the narrative that his experience in Mecca transformed Malcolm X from a superficially religious black nationalist to a "real" Muslim and a color-blind universalist, Islam is a Foreign Country foregrounds the radical and transnational continuities in Malcolm X's thought about race and the 
fight for racial justice before and after the hajj. I explore Malcolm X's enduring political ambivalence toward the US and I argue his agitation for political rights and recognition must be understood as a form of Islamic transnational countercitizenship. In that context, his invocations of Muslim lands and people are fundamental challenges to the idea of the nation-state. An important personal religious experience, the hajj also created the space for Malcolm X to further develop his own transnational moral geography, and he adopted W. E. B. Du Bois' term "the Dark World." The "Dark World" was both metaphor and method for his vision of achieving racial justice in global, rather than national, terms. Malcolm X's moral geography of "the Dark World" drew from and amended the transnational moral geography of Elijah Muhammad, whose utopic Muslim Afro-Asia offered an ethical alternative to the racist dystopia of the US. In contrast, Malcolm X did not idealize postcolonial Muslim majority societies nor did he foreclose the possibility of political redemption for the US. ${ }^{11}$ In addition to the influence of the cosmology of the Nation of Islam, Malcolm X's moral geography of "the Dark World" was also inspired by, but not limited to, the Islamic concept of the umma, the "global community of Muslim locals, both majorities and minorities, who belong to the places where they live and who, in their totality, exemplify the universality of Islam." ${ }^{\prime 2}$ As his private letters make clear, Malcolm X was keenly aware of how Arab Muslim leaders could depoliticize the transnational concept of the umma and delink it from the global fight against white supremacy, which is why he avoided becoming involved in the heated religious debates among Muslims that he observed during his time in the Middle East. My intellectual history of Malcolm X destabilizes terms such as "political Islam" and the "Muslim world" which map the Middle East as Islam's authentic core. Malcolm $\mathrm{X}$ re-maps the Muslim world to include American ghettos and his vision for "the Dark World" was no less political and no less Islamic than that of the members of the Muslim Brotherhood he encountered in Egypt.

De-territorializing the history and historiography of American Islam requires us to account for how global flows of people, capital, ideas, practices, and objects have shaped communities on both sides of the Atlantic and Islam itself in all its diverse, continuous, and discontinuous forms. Islam is a Foreign Country breaks with the persistent territorial bias that maps "true" Islam to distant, eastern lands and brown (rather than black) bodies. Furthermore, my focus on the moral geographies in the religious imagination of American Muslims allows me to sidestep the sectarian, racial, and class divisions that obscure important continuities across diverse American Muslim communities and time periods. Such a transnational framing de-naturalizes the nation-state, modernity's most powerful geographic imaginary, and destabilizes the loaded questions of Americanization that have dominated the sub-field of Islam in the United States. ${ }^{13}$ By foregrounding the American Muslim practice of traveling abroad for religious knowledge, Malcolm X fits in two enduring traditions of travel: American seekers and Islamic pedagogical trips (rihla). Many American Muslim leaders, before and after Malcolm X, linked their claims to religious authority to their travels to 
Muslim lands, whether real or imagined, and the (de-colonial) recovery of lost (sacred, powerful) knowledge. Seeing Malcolm X not only as a Muslim leader and activist but also as an American Muslim seeker allows us to better understand how he drew on geographic metaphors that were simultaneously religious and political in order to talk about race, citizenship, justice, belonging, and what it means to be human. ${ }^{14}$ In other words, Malcolm X's religious studies and travels were a religio-political means to a religio-political end.

As a work of historical ethnography situated between American studies and Islamic studies, my book writes Malcolm X as a religious intellectual into the history of global Islam and it tracks how he figures in contemporary transnational intellectual networks that link US mosques to the intellectual centers in the Middle East. Over the course of interviewing more than a hundred American Muslim seekers in Syria, Jordan, and Egypt—youth from diverse ethnic, racial, and socio-economic backgrounds with a shared radical, transnational politics-I found that Haley's Autobiography was the text most frequently credited with sparking their Islamic reawakening. (Unsurprisingly, most had come of age in the late nineties in the wake of Spike Lee's biopic Malcolm X, which popularized Haley's Autobiography for a new generation.) In addition to documenting the ways Haley's Autobiography operates as a religious text for American Muslims ethnographically, I track the ways the (often de-politicized) figure of Malcolm X-as-seeker figures in the American Muslim imagination in general and in these transnational pedagogical networks in particular. The vignette of a young African-American man memorizing an Arabic dictionary page by page as part of his religious studies in Cairo, consciously replicating the autodidactic habits of Malcolm in prison and demonstrates the imaginative ways American Muslim youth memorialize Malcolm X. Such an act of memorization must be understood not only as a pedagogical and religious ritual, but also as a profoundly political act. ${ }^{15}$

Whether in my own work or in that of Marable, Abernethy, Daulatzai, and Aidi, the vibrancy of debates over what Malcolm X would have lived to do is palpable as is the scholarly significance of his thought and its generative qualities since his brutal murder in 1965. One of the legacies of the cultural turn in the humanities is a pervasive preference for the history of movements, practices, habits, and affects over the history of ideas, often rooted in an anti-elitist impulse. The books examined in this review are models of how to expand the history of ideas to include individuals typically left out of intellectual histories and to ground those ideas within dense cultural histories and ethnography. What is America? What is race? What is Islam? Malcolm X was grappling with these questions, and the scholarly works reviewed here grapple with the global impact of his working ideas: the Muslim International, the science of imagery, the Dark World, and the aspirational soundtrack to his Black Revolution. 


\section{Zareena Grewal}

\section{Notes}

1. For my purposes here, I deal only with what I see as Marable's two key contributions, excavating Malcolm X's intellectual lineage and his internationalist politics. Although it is beyond the scope of my argument, I am deeply skeptical of the speculative dimension of Marable's narrative, both in regards to the personal, biographical details of Malcolm X's private life as well as the political opinions he would have held about the War on Terror had he lived to see September 11, 2001. For a critical response to Marable's work, see Jared A. Ball and Todd Steven Burroughs, A Lie of Reinvention: Correcting Manning Marable's Malcolm X (Baltimore, MD: Black Classic Press, 2012).

2. Manning Marable, Living Black History (New York: Basic Civitas, 2006), 146.

3. Michael Shapiro, "Moral Geographies and the Ethics of Post-Sovereignty," Public Culture 6 (1994): 479-502.

4. Alex Lubin, "Between the Secular and the Sectarian: Malcolm X's Afro-Arab Political Imaginary," Journal of Africana Religions 3, no. 1 (2015): 83-95.

5. Aidi explores Malcolm X's own passion for jazz and his lingering ambivalence in a separate essay: Hisham Aidi "The Music of Malcolm X," New Yorker, February 28, 2015.

6. Zareena Grewal, Islam is a Foreign Country: American Muslims and the Global Crisis of Authority (New York: New York University, 2013).

7. Edward Curtis. "African-American Islamization Reconsidered: Black History Narratives and Muslim Identity," Journal of the American Academy of Religion 73, no. 3 (2005): 659-684 and Yvonne Haddad, Not Quite American?: The Shaping of Arab and Muslim Identity in the United States (Waco, TX: Baylor University Press, 2004).

8. Grewal, Islam is a Foreign Country, 120

9. Sally Howell offers an important corrective to this historiography in Sally Howell, Old Islam in Detroit: Rediscovering the Muslim American Past (New York: Oxford University Press, 2014).

10. Grewal, Islam is a Foreign Country, 111

11. Grewal, Islam is a Foreign Country, 113.

12. Grewal, Islam is a Foreign Country, 7.

13. For a recent example of this trend, see Mucahit Bilici, Finding Mecca in America: How Islam Is Becoming an American Religion (Chicago: University of Chicago Press, 2012).

14. I am building on James Tyner's otherwise excellent work, which neglects the role of religion: James Tyner, The Geography of Malcolm X: Black Radicalism and the Remaking of American Space (New York: Routledge, 2006).

15. Grewal, Islam is a Foreign Country, 80. 


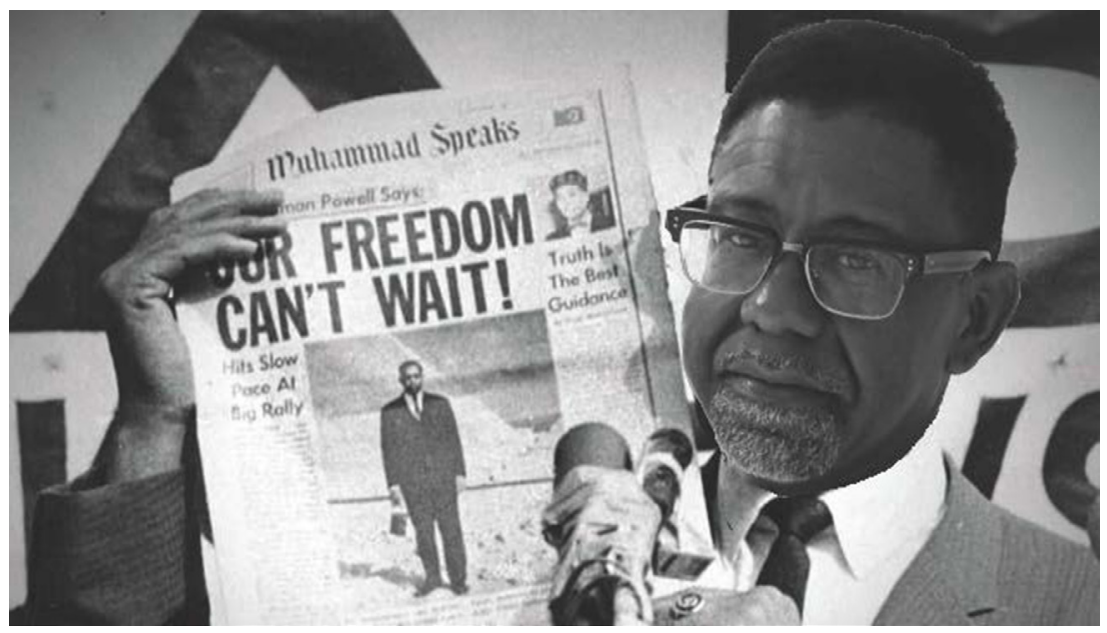

Randal Maurice Jelks, editor, pays homage to Malcolm X holding up a copy of Muhammad Speaks August 6, 1963. 